Яковишина М. С. [1; ORCID ID: 0000-0002-0198-5812], ст. викладач,

Конарівська О. Б. [1; ORCID ID: 0000-0002-1760-9264], к.е.н., доцент,

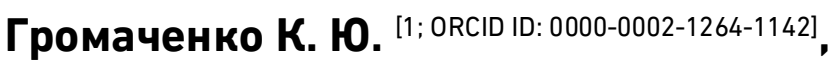
к. С.-Г. Н., доцент, Коротун О. П. [1; ORCID ID: 0000-0002-5628-8301], ст. викладач

${ }^{1}$ Національний університет водного господарства та природокористування, м. Рівне

\title{
ОСОБЛИВОСТІ СТВОРЕННЯ І ФУНКЦІОНУВАННЯ ГАЛУЗЕВОГО МУЗЕЮ ЯК ФОРМИ ПРОМОЦІї ІСТОРИКО-КУЛЬТУРНИХ ТУРИСТИЧНИХ РЕСУРСІВ МІСТА РІВНЕ
}

У статті на основі світового і вітчизняного досвіду створення аптекмузеїв, здійснено оцінювання їх правового середовища діяльності. Визначено профіль аптек-музеїв та їх функції. Доведено, що у світі є великий інтерес туристів до галузевих музеїв, зокрема аптек-музеїв. 3'ясовано, що відповідно до сучасних принципів планування туризму, підхід до сталого розвитку включає залучення приймаючої громади та різних груп зацікавлених сторін до процесу планування туристичної політики. Визначені стейкхолдери у діяльності музеїв та сфері культурнопізнавального туризму: внутрішні стейкхолдери (персонал музеїв); зовнішні стейкхолдери (установи та організації, 3 якими співпрацює музей; туристи, освітні заклади; спонсори). Зазначено, що аптеки-музеї є інтерактивними музеями, які поряд із музейною, виконують свою основну функцію - виготовлення та продаж лікарських препаратів. Проведена характеристика відомих аптек-музеїв і проведено їх групування за регіонами світу. З'ясовано, що в Україні нараховується 12 найбільш відомих аптек-музеїв, які розміщені в обласних центрах. Визначені особливості функціонування аптеки-музею в ресурсному потенціалі культурно-пізнавального туризму міста Рівного. Зазначається, що аптеку-музей у Рівному створено на базі товариства «Рівнефармація» за рахунок приватних інвестицій. Рівненська аптека-музей має вигідне місцерозташування, відсутність конкурентів, але малий простір для відвідувачів. Для здійснення ефективної промоції необхідно врахувати усі групи людей, які приїжджають у дану місцевість. Надано рекомендації щодо розробки тематичних занять і майстер-класів, встановлення фотозон, розробки унікальних сувенірів на фармацевтичну тематику, 
співпраці з туристичними фірмами для залучення туристів. Акцентовано увагу на те, що при розробці екскурсійних сюжетів потрібно поєднувати елементи фармацевтичної спадщини з гастрономічною та іншими видами історико-культурних туристичних ресурсів. Доведено, що аптека-музей сприяє промоції туризму міста, популяризації наукових знань, через експонати музею, котрі мають наукову i пізнавальну цінність. Встановлено, що в місті Рівне ведеться системна робота щодо підвищення туристичної привабливості, регулярно створюються нові туристичні об'єкти.

Ключові слова: аптека-музей; галузевий музей; екскурсійна діяльність; промоція; історико-культурна спадщина; культурнопізнавальний туризм; музей фармації; ресурсний потенціал; туристичний продукт.

Постановка проблеми. Розвиток туристичної галузі $є$ одним 3 пріоритетних напрямків у діяльності кожного регіону України. Тому нині актуальним $€$ урізноманітнення пропозицій щодо організації дозвілля та пошуку нових форм промоції історико-культурної спадщини рідного краю. У період пандемії COVID-19 та закриття кордонів між державами інтерес до внутрішнього туризму зріс у рази. Важливими партнерами індустрії туризму є музеї, які щоденно в цілому світі приймають мільйони людей, котрі прагнуть розширити свої знання і зустрітися з прекрасним. Зокрема, значної уваги варті регіональні музейні ресурси як частина туристичної інфраструктури регіону.

Нині місто Рівне не має великої кількості історико-культурних пам'яток, оскільки давня архітектура майже не збереглась. Проте, одним із потужних інструментів залучення туристів $€$ правильно організована екскурсійна діяльність, де частиною екскурсійної програми досить часто виступає музейи як культурно-пізнавальний ресурс. Таким чином, питання розвитку культурно-пізнавального туризму на сьогодні в Україні і світі $€$ надзвичайно актуальним, оскільки культурні ресурси із своїми локальними, регіональними, етнічними, національними відмінностями $€$ важливими духовними цінностями, які фахівці у сфері туризму перетворюють на туристичний продукт і створюють додану вартість [5].

Дослідженням проблем розвитку культурно-пізнавального туризму в Україні та світі займались такі науковці: О.Аріон, О.Бейдик, А. Дурович, О. Любіцева, М.Кляп, Д. Стеченко, С. Уліганець, В. Федорченко, Л. Черчик, Л. Яцунта та інші.

На сьогодні іноземними науковцями підготовлено ряд 
публікацій, присвячених аптекам-музеям. Зокрема, Андреас Зіглер [14] вивчав історію європейських аптек-музеїв, Ана Делікадо [8] досліджувала португальські музеї медицини та фармації, Дж. Гриффенгаген, Е. Стіб, Б. Фішер [9] видали путівник по музеях фармації та історичних колекціях у США та Канаді тощо. Водночас, аптеки-музеї як об'єкти культурно-пізнавального туризму потребують додаткової промоції. Викладене обумовило вибір теми і мети дослідження.

Мета дослідження: на основі світового і вітчизняного досвіду створення і функціонування галузевих музеїв, визначити особливості створення і функціонування аптеки-музею м. Рівне, зробити оцінювання середовища його діяльності 3 метою проведення промоційних заходів у плані розвитку культурно-пізнавального туризму. Для досягнення поставленої мети були окреслені завдання: розглянути досвід функціонування аптек-музеїв у світі та в Україні, визначити стейкхолдерів для сектору культурно-пізнавального туризму, розробити рекомендації щодо ефективної промоції туристичного потенціалу аптеки-музею м. Рівне.

Виклад основного матеріалу. Основою для публікації став аналіз інформаційних ресурсів про музеї-аптеки на туристичних вебплатформах окремих країн [10; 12-13; 15].

Історико-культурна спадщина $€$ основним ресурсом для культурно-пізнавального туризму та формування музейних колекцій. Вклад туризму найчастіше цінується за його економічний внесок та той факт, що він також може покращити існуючу інфраструктуру. Музеї часто відіграють важливу роль, коли йдеться про розробку політики у сфері культури та освіти країни. Значну соціальну роль відіграють аптеки-музеї у просуванні розуміння громадськістю значення охорони здоров'я та фармацевтичної науки, а також охороні історичної спадщини. На жаль, потенціал музеїв часто недооцінюється у процесі розробки національної та місцевої культурної політики [11].

у м. Рівне найбільші колекції зібрані у Рівненському краєзнавчому музеї і двох його відокремлених відділах: музеї бурштину та літературному музеї Уласа Самчука. Крім того, у місті діє приватний музей ковальського мистецтва «Ковальські витребеньки», музей фотографії, а в березні 2020 року офіційно відкрився аптека-музей [4].

Варто зазначити, що в умовах розвитку сучасного суспільства має місце «музеєзація» культурних та комерційних організацій коли немузейні заклади за рахунок власних інвестицій створюють різноманітні колекції [5]. Зокрема, аптеку-музей у Рівному відкрито 
Серія «Економічні науки»

Випуск 3(95) 2021 р.

на базі товариства «Рівнефармація», тобто створено за рахунок приватних інвестицій. Засновники рівненської аптеки-музею власними силами зібрали колекцію та у своїй аптеці облаштували музей [4].

Досвід створення різних напрямів культурно-пізнавального туризму говорить про те, що у даній сфері необхідно розвивати рівноправне партнерство різних за профілем закладів, об'єднаних спільною метою. Така співпраця - це постійний процес взаємокоординації та інтеграції на основі спільності інтересів у розвитку туристичної індустрії в регіоні, тобто пізнавальнокультурний сектор і туристичний сектор повинні докласти зусиль для промоції один одного й співпрацювати так, щоб мати взаємний зиск від цього [5].

Відповідно до сучасних принципів планування туризму, підхід до сталого розвитку включає залучення приймаючої громади та різних груп зацікавлених сторін до процесу планування туристичної політики. Успіх значною мірою залежить від того, наскільки можливо для різних зацікавлених сторін об'єднатися для досягнення одних і тих же цілей. Спільний підхід до проблеми згодом призводить до більш стійкого розвитку туризму [7].

У сфері культурно-пізнавального туризму виділяють багато зацікавлених сторін, кожна з яких має свої інтереси. Можна виокремити основні 4 групи стейкхолдерів: 1) внутрішні стейкхолдери - персонал музею; 2) установи та організації, з якими співпрацює музей; 3) окремі відвідувачі, туристи, освітні заклади; 4) спонсори [7].

Велика група стейкхолдерів у туризмі представляють інтереси немісцевих громад, тих, хто знаходиться поза межами дестинації, наприклад, туристичні агентства та підприємства, авіалайнери, міжнародні організації i, звичайно, туристи, які є споживачами. Для прикладу зацікавлених сторін у туризмі у межах окремого регіону можна навести мешканців приймаючої громади, широку громадськість та місцеві органи влади. Музеї та об'єкти культурної спадщини, які залучають туристів, зазвичай теж виступають частиною групи стейкхолдерів.

Стейкхолдери аптеки-музею - це люди, які «зацікавлені у музейній політиці й фармацевтичній сфері» i, враховуючи великі зобов'язання музеїв перед суспільством, очевидним $€$ те, що у них існує кілька зацікавлених сторін з різними інтересами, потребами та очікуваннями. Музейна діяльність та туристична діяльність можуть мати різний погляд на стейкхолдерів та різний підхід до ресурсів. 
Наприклад, аптека-музей може вважати основною своєю функцією збереження історико-культурних цінностей, зокрема, різних фармацевтичних артефактів, тоді як організація туризму на базі аптекимузею передбачає використання даного активу як туристичної атракції [7].

Популяризації і розвитку означеним процесам сприяє і чинне законодавство України. Розглянемо детальніше основні статті. Так, у статті 7 Закону України «Про музеї та музейну справу» зазначено, що музеї можуть засновуватися на будь-яких формах власності, засновниками музеїв можуть бути відповідні органи виконавчої влади, органи місцевого самоврядування, юридичні та фізичні особи. Для створення музею засновники повинні забезпечити: формування музейного зібрання, матеріальну базу, фінансування та кадри для належного його функціонування, тощо. Також, у даному законі дається визначення музею та музейної колекції: «...музей - науководослідний та культурно-освітній заклад, створений для вивчення, збереження, використання та популяризації музейних предметів та музейних колекцій 3 науковою та освітньою метою, залучення громадян до надбань національної та світової культурної спадщини»; «...музейна колекція - сукупність музейних предметів, що об'єднані однією або кількома спільними ознаками» [6, С. 1].

За профілем музеї поділяються на природничі (антропологічні, біологічні, ботанічні, геологічні, зоологічні, мінералогічні, палеонтологічні), історичні (загальноісторичні, військово-історичні, історії релігії, історико-побутові, археологічні, етнографічні), літературні, художні (образотворчого, декоративно-прикладного, народного, сучасного мистецтва), мистецькі (театральні, музичні, музеї кіно), науково-технічні, комплексні (краєзнавчі, екомузеї), галузеві [6, С. 6].

Отже, можна стверджувати, що за профілем музей-аптека належить до галузевого музею, а саме музею фармації.

Музеї фармації мають довгу історію. Згідно досліджень Гриффенхангена, Стіба та Фішера, найдавніший приклад експонатів фармацевтичної історії можна знайти в реконструкції аптекарського магазину в Дрезденському музеї у XVII столітті. Пізніше виникли спеціалізовані музеї фармації: Музей Королівського фармацевтичного товариства в Лондоні з 1842 р., Музей фармації Базельського університету з 1924 р., Німецький фармацевтичний музей з 1938 р. та Краківський фармацевтичний музей з 1946 р. У 1930-x роках існували понад 230 фармацевтичних колекцій у Європі [9].

Існування музеїв засноване на ідеї піднесення історичних 
цінностей нації. Історія фармації в різних цивілізаціях та географічних районах спрямована на наголос на універсальності боротьби за здоров'я та пошуку ефективних лікарських засобів. Одні аптеки-музеї мають схожість з музеями історії науки, бо містять наукові прилади та обладнання, інші - ознаки природознавчих музеїв із колекціями збережених зразків цілющих рослин та органів тварин [8].

Засновниками музеїв фармації часто виступають університети, лікарні, медичні товариства, фармацевтичні підприємства, які намагаються викликати громадський інтерес, оскільки він підвищує престиж їхніх закладів та медичної професії, а також пропагує здоровий спосіб життя. В аптеках-музеях досить часто представлені різноманітні колекції приладів для фармації, фізики й хімії та фармацевтичного інструментального аналізу, які мають видатне наукове, викладацьке та музейне значення. Такі колекції демонструють високий рівень досліджень фармації в минулому.

Аптеки-музеї $є$ інтерактивними музеями, які поряд із музейною, виконують свою основну функцію - виготовлення та продаж лікарських препаратів. Розглянемо досвід функціонування таких музеїв у світі і в Україні. На основі даних інтернет-ресурсів Atlas Obscura та ін. [10; 12-13; 15], нами подано перелік найбільш відомих аптек-музеїв у країнах світу і здійснено групування за регіонами: Північна Америка, Європа, Австралія, Азія (таблиця).

Таблиця

Відомі аптеки-музеї у світі

\begin{tabular}{|c|l|l|}
\hline $\begin{array}{c}\text { № } \\
\text { з/п }\end{array}$ & \multicolumn{1}{|c|}{ Назва аптеки-музею } & \multicolumn{1}{|c|}{ Місцезнаходження } \\
\hline \multicolumn{3}{|c|}{ ПІВНІЧА АМЕРИКА } \\
\hline 1. & Аптекарський магазин Нugh Mercer & Фредеріксбург, Вірджинія \\
\hline 2. & Музей фармації Нового Орлеана & Новий Орлеан, Луїзіана \\
\hline 3. & Магазин Сhew Кеe & Фідлдаун, Каліфорнія \\
\hline 4. & Історія музею фармації & Туксон, штат Арізона \\
\hline \multicolumn{3}{|c|}{ ЄВРОПА } \\
\hline 5. & $\begin{array}{l}\text { Музей старого операційного театру та } \\
\text { Герб Гаррет }\end{array}$ & Лондон, Англія \\
\hline 6. & Музей університету Гельсінкі & Гельсінкі, Фінляндія \\
\hline 7. & Svапеаротеk історичний музей & Ольборг, Данія \\
\hline 8. & $\begin{array}{l}\text { Аптечний Швейцарія } \\
\text { Базельського університету }\end{array}$ \\
\hline
\end{tabular}


продовження таблиці

\begin{tabular}{|c|l|l|}
\hline 9. & Гетеборзький історичний музей & Гетеборг, Швеція \\
\hline 10. & Аптека Санта Марія Новелла & Флоренція, Італія \\
\hline 11. & Esteve Pharmacy & Львівія, Іспанія \\
\hline 12. & $\begin{array}{l}\text { Fekete Sas Patikamúzeum. Аптечний } \\
\text { музей «Чорний орел» }\end{array}$ & Секесфехервар, Угорщина \\
\hline 13. & Музей фармації «Золотий Орел» & Будапешт, Угорщина \\
\hline 14. & $\begin{array}{l}\text { Музей історії литовської медицини та } \\
\text { фармації }\end{array}$ & Каунас, Литва \\
\hline 15. & Музей фармації & Клуж-Напока, Румунія \\
\hline 16. & Аптечний музей Сібіу & Сібіу, Румунія \\
\hline 17. & Під Музеєм фармації «Чорний орел» & Львів, Україна \\
\hline 18. & Музей фармації & Лісабон, Португалія \\
\hline 16. & Музей фармації & Краків, Польща \\
\hline \multicolumn{3}{|c|}{ АВСТРАЛІЯ } \\
\hline 20. & Мельбурнський медичний музей & Парквіль, Австралія \\
\hline \multicolumn{3}{|c|}{ АЗІЯ } \\
\hline 21. & $\begin{array}{l}\text { Музей традиційної китайської медицини } \\
\text { Хунчжоу, Китай }\end{array}$ \\
\hline
\end{tabular}

Джерело: згруповано авторами за даними [10; 12-13; 15]

Отже, у наведений перелік увійшли лише ті аптеки-музеї, які є найбільш пізнаваними і привабливими для туристів. Відмітимо, що аналіз за континентами показав, що відомих аптек-музеїв немає в Африці і Південній Америці. Проте $€$ багато аптек-музеїв, які не входять до цього переліку, але $€$ також цікавими для туристів, зокрема в Україні є 12 аптек-музеїв: аптека-музей на Подолі в Києві, аптека-музей у Чернігові, аптека Михайла Лігди у Ніжині, аптека Пирогова у Вінниці, аптека-музей «Крещатикъ»у Черкасах, аптекамузей у Рівному, аптека-музей Злоцьких у Луцьку, аптека Фрідріхсона в Ковелі, МКП «Аптека № 2» у Чернівцях, аптека «Під чорним орлом» у Львові, «D.S. Таємна аптека» у Львові, аптекамузей у Харкові [1].

Досвід функціонування аптек-музеїв у світі та їх різноманіття засвідчує інтерес туристів до галузевих музеїв (музеїв фармації). Найбільший досвід у функціонуванні аптек-музеїв має Львів. Позитивним моментом у нашому дослідженні $€$ той факт, що до переліку відомих аптек-музеїв світу увійшов український музей фармації «Чорний орел». Але в туристичному місті Львові $€$ й багато інших історичних автентичних аптек, у яких зберігся старовинний інтер'єр та меблі. Саме зі Львовом історики пов'язують і найдавнішу 
згадку про аптеки на території сучасної України. Першу аптеку ще у 1270-х роках заснувала при Домініканському монастирі Констанція, дружина князя Лева [3].

Серед найбільш популярних локацій Львова туристи виділяють Музей «D.S. Таємна аптека». Що й не дивно, адже аптеки теж виступають як частка історії міста. Аналізуючи вебсайт інтерактивного львівського музею фармації «D.S. Таємна аптека» можна сказати про його багате інформаційне наповнення: легенди міста, пов'язані з фармацією, цікаві факти про фармацевтичні винаходи, фото екскурсій та майстер-класів [3].

У місті Рівне аптеку-музей відкрито в найстарішій аптеці міста, що містить дві зали - перша частина являє собою звичайну аптеку 3 продажу ліків, а друга зала подібна до музейної кімнати, де можна побачити унікальне аптекарське обладнання різних епох. Зокрема, у Рівненській аптеці-музеї можна побачити сторічний стілець i автентичну скриню аптекаря, сторічний касовий апарат, за допомогою якого не лише фіксували продаж препаратів, а й вели облік клієнтів та відкривали кредити для купівлі ліків. Колби, мензурки, аптечні терези, стародавні кам'яні ступки, пілюльні машини - усі ці раритети звозили до рівненської аптеки-музею 3 усієї України. В аптеці плануються інтерактивні екскурсії та майстеркласи, які будуть проводити фармацевти [2]. Відмітимо вдале розташування рівненської аптеки-музею - на центральній вулиці міста - близько до туристичних атракцій, поряд із органним залом та майданом музики, що створює в перспективі чудову можливість включити даний об'єкт в оглядову екскурсію містом. 3 точки зору організації туристичних груп дана аптека-музей має недолік обмежена пропускна спроможність (зала для майстер-класів може вмісити не більше 12 осіб). Але велике прагнення місцевих органів влади розвивати культурний туризм та інноваційні маркетингові зусилля засновників аптеки-музею, допоможуть розширити туристичний потенціал аптеки-музею у місті Рівне.

Як нами було зазначено вище, для сектору культурнопізнавального туризму важливо виділити зацікавлені сторони в роботі музеїв та їх інтереси, що дозволить працювати в гармонії 3 місцевим середовищем. Рівненська аптека-музей зосереджує увагу на освіті школярів (робота гуртків хіміко-біологічного профілю) $\mathrm{i}$ студентів медичного коледжу (лабораторні і практичні заняття для майбутніх фармацевтів). Туристи, що приїжджають у Рівне, можуть мати різну освіту, культуру, соціальний статус та різні інтереси. Для збільшення привернення уваги до аптеки-музею варто розмістити 
цікаву фотозону, розробити унікальні сувеніри, проводити тематичні дійства та майстер-класи, приурочені до різноманітних заходів у місті. Наприклад, з нагоди відзначення певної події чи річниці, варто організовувати театралізовані перфоманси на фармацевтичну тематику із демонстрацією хімічних дослідів та майстер-класів із заготівлі дикорослих лікарських трав, які можна проводити не лише у приміщенні аптеки-музею, а й вільно спостерігати на прилеглій до нього території. У цьому аспекті рівненська аптека-музей має зручне розташування - недалеко від рекреаційної зони річки Устя.

Враховуючи той факт, що за 350 м від аптеки-музею знаходиться цікава архітектурна локація міста Рівне «Європейський квартал», варто поєднати два даних об'єкти за допомого екскурсії, в якій можна використати елементи фармацевтичної і гастрономічної спадщини. Адже, фармацевти часто робили винаходи, не пов'язані із аптечною справою, наприклад, винахід напою «Кока-кола» [3].

Для промоції аптеки-музею рекомендуємо також обрати популярні маршрути (об'єкти) із значним туристичним потоком, які знаходяться по сусідству, та стати їх маршрутом-супутником. Оскільки поряд із містом Рівне знаходиться всесвітньо відома атракція Тунель кохання, то з метою залучення відвідувачів до аптеки-музею, необхідно співпрацювати з туристичними агенціями, які організовують тури у Клевань до даної туристичної пам'ятки, для включення аптеки-музею в маршрут як пункту відвідування.

Варто зазначити, що функції аптеки-музею різноманітні і залежать від різних учасників. Наприклад, фармацевтичні професійні асоціації насамперед переймаються «збереженням спадщини професії», тому функцію даного музею вбачають у спонуканні до роздумів про історичну та культурну природу професії, сприянні, щоб ії наукова, технологічна та мистецька спадщина була передана майбутнім поколінням. Тобто для таких фармацевтичних об'єднань аптека-музей є посередником у зв'язках із громадськістю та інструментом просування громадського іміджу професії та самої асоціації. Для директора аптеки-музею - це інструмент для наукового та історичного розповсюдження та відповідь на інтерес громадськості до теми охорони здоров'я. Тобто у даному випадку функція музею - охопити громадськість, показати людям історію фармації.

Отже, особливостями функціонування аптеки-музею в ресурсному потенціалі культурно-пізнавального туризму міста Рівного $є$ : збереження історико-культурної спадщини; проведення 
промоційних заходів у плані розвитку культурно-пізнавального туризму міста Рівне; поєднання різних видів екскурсій; спрямування на проведення театралізованих екскурсій, квестів, експериментів, організації дитчяих днів народження тощо; використання різноманітних анімаційних елементів, популярних серед шкільних груп, особливо молодшого та середнього шкільного віку, коли за допомогою застосування інтерактивних технологій можна проводити уроки, деяких шкільних предметів, що може пробудити інтерес до вивчення хімії і фізики, а також проведення практичних та лабораторних занять для студентів фармакологічних спеціальностей.

Висновки. Промоція музею сьогодні - це стратегічне завдання будь-якого плану розвитку туризму на рівні регіону, у якому знаходиться об'єкт, тобто завдання для організаторів культурнопізнавального туризму з використанням аптеки-музею міста Рівне мають носити і організаційний, і промоційний, і стратегічний характери, зокрема збір інформації про історію та особливості створення, характеристику середовища діяльності та специфіку функціонування, визначення туристичної спеціалізації галузевого музею і формування постійних туристичних потоків, складання програм і маршрутів, формування рекламної продукції, пошук джерел фінансування тощо.

Вважаємо, що екскурсії до аптеки-музею м. Рівне будуть популярні не тільки серед груп школярів і студентів, а й мешканців і гостей міста. Аптека-музей буде сприяти промоції туризму міста, популяризації наукових знань, адже експонати музею мають наукову і пізнавальну цінність, допомагають при вивченні хімії, фізики, математики і формуванню природничого світогляду.

Отже, планування, розвиток і функціонування туризму у місті має бути інтегрованим та базуватись на співпраці та залученні різних стейкхолдерів: державних органів місцевого управління, бізнесу, громадських організацій, науковців, туристичних операторів i турагентів, інших зацікавлених сторін. Розвиток стійкого туризму у регіоні можливий лише за підтримки і стимулювання держави, оскільки він впливає на соціально-економічний розвиток як окремого регіону, так і країни загалом. А предметом наших подальших досліджень стане визначення ефективності промоції історико-культурних туристичних ресурсів міста Рівне, зокрема від поєднання різних елементів фармацевтичної, гастрономічної, природної та історико-культурної спадщини міста Рівне. 
1. Відкриті навіть у карантин! ТОП-12 аптек-музеїв України. Zruchno. Travel : вебсайт.

https://zruchno.travel/Publications/Entry/5063?lang=ua\&fbclid=IwAR3Rm6H15-

LDeoCMiOusfVoVRRXTzjxcRDTjGJnrpyPERkkCEUE4EXu_Hgg (дата звернення: 15.09.2021). 2. Десять цікавинок з історії аптечної справи у Рівному. 3 нагоди відкриття в місті аптеки-музею. Рівне Ретро Ритм : вебсайт. URL: http://retrorivne.com.ua/desjat-cikavinok-z-istorii-aptechnoi-spravi-u-rivnomu-znagodi-vidkrittja-v-misti-apteki-muzeju/ (дата звернення: 15.09.2021). 3. D.S. Таємна аптека : вебсайт. URL: http://secret.lviv.ua/ua/(дата звернення: 15.09.2021). 4. Конарівська О. Б., Яковишина М. С. Оцінювання середовища діяльності аптекимузею в ресурсному потенціалі культурно-пізнавального туризму міста Рівне. Стратегії інноваційного розвитку туризму та готельно-ресторанної справи проблеми та перспективи : тези Всеукраїнської науково-практичної online конференції здобувачів вищої освіти і молодих учених, присвяченої Дню науки, 11-15 травня 2020 р. Житомир : Державний університет «Житомирська політехніка», 2020. С. 921-924. 5. Мазурик 3. В. Туризм як виклик для музеїв. Вісник ДІТБ. Сер. Економіка, організація і управління підприємствами (в туристичній сфері). 2006. № 10. С. 235-238. 6. Про музеї та музейну справу : Закон України від 29.06.1995 № 249/95-BP, Редакція від 05.02.2020. URL: https://zakon.rada.gov.ua/laws/show/249/95-\%D0\%B2\%D1\%80. (дата звернення: 15.09.2021). 7. Abuselidze G., Devadze N. Stakeholders and Their Role in Sustainable Tourism Development / Conference : Biannual International Scientific Practical Conference SEU ISC 2018. Georgian National University SEU May 2018. 8. Delicado A. The Past and Present of Medical Museums in Portugal. Museum History Journal. January, 2014. Vol. 7 No. 1. P. 18-35. DOI: 10.1179/1936981613Z.00000000019. 9. Griffenhagen G. B., Stieb E. W., Fisher B. D. A Guide to Pharmacy Museums and Historical Collections in the United States and Canada. Madison, WI: American Institute of the History of Pharmacy, 1999. 10. Hu Qing Yu Tang - Living Class to Know Traditional Chinese Medicine Chana Discovery. URL: https://www.chinadiscovery.com/zhejiang/hangzhou/hu-qing-yu-tang.html (accessed: 12.09.2021). 11. Benediktsson G. Museums and tourism Stakeholders, resource and sustainable development : Master's Dissertation. International Museum Studies Museion / Göteborg University Spring term 2004. 12. Muzeum farmacji. muzeumfarmacji.uj.edu.pl. URL: https://muzeumfarmacji.uj.edu.pl/ (accessed: 12.09.2021). 13. Pharmacy museum. URL: https://www.museudafarmacia.pt/EN/museu_en.htm (accessed: 12.09.2021). 14. Ziegler A. S. Das Pharmazie-museum Krakau. Deutsche Apotheker Zeitung 2015. URL: https://www.deutsche-apotheker-zeitung.de/daz-az/2015/daz-32-2015/daspharmazie-museum-krakau (accessed: 12.09.2021). 15. What Ho, Apothecary! 18 Intriguing Pharmacy Museums. AtlasObscura URL: https://www.atlasobscura.com/lists/pharmacy-museums-world (accessed: 12.09.2021).

\section{REFERENCES:}

1. Vidkryti navit u karantyn! TOP-12 aptek-muzeiv Ukrainy. Zruchno. Travel : vebsait. URL: https://zruchno.travel/Publications/Entry/5063?lang=ua\&fbclid=IwAR3Rm6H15- 
LDeoCMiOusfVoVRRXTzjxcRDTjGJnrpyPERkkCEUE4EXu_Hgg (data zvernennia: 15.09.2021). 2. Desiat tsikavynok $z$ istorii aptechnoi spravy u Rivnomu. $Z$ nahody vidkryttia $v$ misti apteky-muzeiu. Rivne Retro Rytm : vebsait. URL: http://retrorivne.com.ua/desjat-cikavinok-z-istorii-aptechnoi-spravi-u-rivnomu-znagodi-vidkrittja-v-misti-apteki-muzeju/ (data zvernennia: 15.09.2021). 3. D.S. Taiemna apteka : vebsait. URL: http://secret.lviv.ua/ua/(data zvernennia: 15.09.2021). 4. Konarivska O. B., Yakovyshyna M. S. Otsiniuvannia seredovyshcha diialnosti aptekymuzeiu v resursnomu potentsiali kulturno-piznavalnoho turyzmu mista Rivne. Stratehii innovatsiinoho rozvytku turyzmu ta hotelno-restorannoi spravy problemy ta perspektyvy : tezy Vseukrainskoi naukovo-praktychnoi online konferentsii zdobuvachiv vyshchoi osvity i molodykh uchenykh, prysviachenoi Dniu nauky, 11-15 travnia $2020 \mathrm{r}$. Zhytomyr : Derzhavnyi universytet «Zhytomyrska politekhnika», 2020. S. 921-924. 5. Mazuryk Z. V. Turyzm yak vyklyk dlia muzeiv. Visnyk DITB. Ser. Ekonomika, orhanizatsiia i upravlinnia pidpryiemstvamy (v turystychnii sferi). 2006. № 10. S. 235238. 6. Pro muzei ta muzeinu spravu : Zakon Ukrainy vid 29.06.1995 № 249/95-VR, Redaktsiia vid 05.02.2020. URL: https://zakon.rada.gov.ua/laws/show/249/95\%D0\%B2\%D1\%80. (data zvernennia: 15.09.2021). 7. Abuselidze G., Devadze N. Stakeholders and Their Role in Sustainable Tourism Development / Conference : Biannual International Scientific Practical Conference SEU ISC 2018. Georgian National University SEU May 2018. 8. Delicado A. The Past and Present of Medical Museums in Portugal. Museum History Journal. January, 2014. Vol. 7 No. 1. P. 18-35. DOl: 10.1179/1936981613Z.00000000019. 9. Griffenhagen G. B., Stieb E. W., Fisher B. D. A Guide to Pharmacy Museums and Historical Collections in the United States and Canada. Madison, WI: American Institute of the History of Pharmacy, 1999. 10. Hu Qing Yu Tang - Living Class to Know Traditional Chinese Medicine Chana Discovery. URL: https://www.chinadiscovery.com/zhejiang/hangzhou/hu-qing-yu-tang.html (accessed: 12.09.2021). 11. Benediktsson G. Museums and tourism Stakeholders, resource and sustainable development : Master's Dissertation. International Museum Studies Museion / Göteborg University Spring term 2004. 12. Muzeum farmacji. muzeumfarmacji.uj.edu.pl. URL: https://muzeumfarmacji.uj.edu.pl/ (accessed: 12.09.2021). 13. Pharmacy museum. URL: https://www.museudafarmacia.pt/EN/museu_en.htm (accessed: 12.09.2021). 14. Ziegler A. S. Das Pharmazie-museum Krakau. Deutsche Apotheker Zeitung 2015. URL: https://www.deutsche-apotheker-zeitung.de/daz-az/2015/daz-32-2015/daspharmazie-museum-krakau (accessed: 12.09.2021). 15. What Ho, Apothecary! 18 Intriguing Pharmacy Museums. AtlasObscura URL: https://www.atlasobscura.com/lists/pharmacy-museums-world laccessed: 12.09.2021). 
Yakovyshyna M. S. [1; ORCID ID: 0000-0002-0198-5812],

Senior Lecturer,

Konarivska O. B. ${ }^{[1 ; 0 R C I D ~ I D: ~ 0000-0002-1760-9264], ~}$ Candidate of Economics (Ph.D.), Associate Professor,

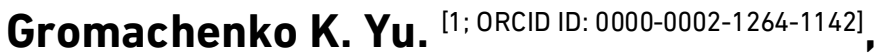
Candidate of Agricultural Sciences (Ph.D.), Associate Professor,

Korotun O. P. [1; ORCID ID: 0000-0002-5628-8301], Senior Lecturer

${ }^{1}$ National University of Water and Environmental Engineering, Rivne

\section{PECULIARITIES OF CREATION AND FUNCTIONING OF THE BRANCH MUSEUM AS FORMS OF HISTORICAL AND CULTURAL TOURIST RESOURCES PROMOTION OF THE CITY OF RIVNE}

In the article based on the world and domestic experience of creation of pharmacy museum, the estimation of their legal environment of activity is carried out. The profile of pharmacy museums and their functions are determined. It is proved that the world has a great interest of tourists in industry museums, in particular, pharmacy museums. It is emphasized that in accordance with modern principles of tourism planning, the approach to sustainable development includes the involvement of the host community and various stakeholder groups in the process of tourism policy planning. Identified stakeholders in the activities of museums and the field of cultural and cognitive tourism: internal stakeholders (museum staff); institutions and organizations with which the museum cooperates; tourists, organized tourist groups, educational institutions; sponsors. It is noted that pharmaciesmuseums are a kind of interactive museum, which, along with the museum, perform their main function - the manufacture and sale of drugs. The list of the most famous pharmacy museums and their grouping by regions of the world is given. It was found that in Ukraine there are 12 most famous pharmacy museums, which are located in regional centers. The peculiarities of the functioning of the pharmacy museum in the resource potential of the cultural and cognitive tourism of the city of Rivne are determined. It is noted that the pharmacy museum in Rivne was created based on the company «Rivnepharmatsiya» at the expense of private investment. Rivne PharmacyMuseum has a favorable location, no competitors, but little space for visitors. To carry out effective promotion, it is important to consider all groups of people who come to the area. It is necessary to develop ideas for thematic classes and masterclasses, to establish an interesting photo area, to develop unique souvenirs on pharmaceutical topics, to cooperate with travel agencies to attract tourists. It is necessary to combine elements of pharmaceutical heritage with gastronomic heritage and other types of 
historical and cultural tourist resources when developing excursion plots. The pharmacy museum will promote tourism in the city, popularize scientific knowledge because the museum's exhibits have scientific and cognitive value. It is emphasized that in the city of Exactly systematic work on increase of tourist attractiveness is conducted, new tourist objects are regularly created.

Keywords: pharmacy museum; branch museum; excursion activity; promotion; historical-cultural heritage; cultural-cognitive tourism; museum of pharmacy; resource potential; tourist product.

\author{
Яковишина М. С. [1; ORCID ID: 0000-0002-0198-5812], \\ ст. преподаватель, \\ Конаривская О. Б. [1; ORCID ID: 0000-0002-1760-9264], \\ к. э. н., доцент, \\ Громаченко К. Ю. [1; ORCID ID: 0000-0002-1264-1142], \\ K. C.-Х. Н., доцент, \\ Коротун О. П. ${ }^{[1 ;}$ ORCID ID: 0000-0002-5628-8301], \\ ст. преподаватель
}

${ }^{1}$ Национальный университет водного хозяйства и природопользования, г. Ровно

\title{
ОСОБЕННОСТИ СОЗДАНИЯ И ФУНКЦИОНИРОВАНИЯ ОТРАСЛЕВОГО МУЗЕЯ КАК ФОРМЫ ПРОМОЦИИ ИСТОРИКО-КУЛЬТУРНЫХ ТУРИСТИЧЕСКИХ РЕСУРСОВ ГОРОДА РОВНО
}

В статье на основе мирового и отечественного опыта создания аптек-музеев проведена оценка их правовой среды деятельности. Определен профиль аптек-музеев, их функции. Доказано, что в мире существует большой интерес туристов к отраслевым музеям, в частности, аптекам-музеям. Подчеркнуто, что согласно современным принципам планирования туризма, подход к устойчивому развитию включает привлечение принимающей общины и различных групп заинтересованных сторон в процесс планирования туристической политики. Определены стейкхолдеры в деятельности музеев и сфере культурно-познавательного туризма: внутренние стейкхолдеры (персонал музеев); учреждения и организации, с которыми сотрудничает музей; туристы, организованные туристические группы, образовательные заведения; спонсоры. Отмечено, что аптеки-музеи являются своеобразными интерактивными музеями, которые наряду с музейной выполняют свою основную функцию - изготовление и продажу лекарственных препаратов. Приводится список наиболее известных аптек-музеев и проведена их группировка по регионам мира. 182 
Установлено, что в Украине насчитывается 12 наиболее известных аптекмузеев, которые размещены в областных центрах. Определены особенности функционирования аптеки-музея в ресурсном потенциале культурно-познавательного туризма города Ровно. Отмечается, что аптека-музей в Ровно создан на базе общества «Ровнофармация» за счет частных инвестиций. Ровенская аптека-музей имеет выгодное месторасположение, у неё нет конкурентов, но имеет мало пространства для посетителей. Для эффективного продвижения аптеки-музея важно учесть все группы людей, приезжающих в данную местность. Необходимо разработать идеи для тематических занятий и мастерклассов, установить интересную фотозону, разработать уникальные сувениры на фармацевтическую тематику, сотрудничать с туристическими фирмами для привлечения туристов. Следует при разработке экскурсионных сюжетов сочетать элементы фармацевтического наследия с гастрономическим наследием и другими видами историко-культурных туристических ресурсов. Аптека-музей будет способствовать продвижению туризма города, популяризации научных знаний, ведь экспонаты музея имеют научную и познавательную ценность. Подчеркивается, что в городе Ровно ведется системная работа по повышению туристической привлекательности, регулярно создаются новые туристические объекты.

Ключевые слова: аптека-музей; отраслевой музей; экскурсионная деятельность; продвижение; историко-культурное наследие; культурнопознавательный туризм; музей фармации; ресурсный потенциал; туристический продукт. 